\title{
WEAPONS OF THE TWO AFRICAN RHINOCEROSES
}

\author{
By Captain Cirarles R. S. Pitman
}

In Oryx, November, 1955, there is an interesting note by Mr. E. O. Shebbeare-" Weapons of the Great Indian Rhinoceros"-indicating that this rhinoceros uses a pair of "tushes", in the lower jaw, as its weapons of offence, and he asks the question whether the African rhinos actually use their horns as weapons.

Mr. R. W. Hayman of the British Museum (Natural History) tells me that all three species of Asiatic rhinos have in adults a pair of sharp-edged, sharp-pointed lower front teeth or "tushes", sometimes described as outer incisors, sometimes as lower canines. The single pair of upper incisors are broad and flat and provide abrasion by which the edges of the lower "tushes" remain razor-sharp. The middle pair of incisors are rudimentary and often lacking. An interesting account of the way the Indian rhino attacks, using its " tushes ", appeared in Illustrated London Neros, 27th August, 1955, p. 344.

In Africa, neither the black nor the white rhinoceros have any incisors which rules out the method of offence of the Indian species. That both species of African rhinoceros use their horns as weapons of offence is well known to anyone familiar with these species in their natural habitat. In fact, reports of injuries or fatalities caused by the black rhino, the commoner of the two species, rarely specifically mention their direct origin, it being taken for granted that the damage is horn inflicted.

The black rhinoceros, a short-sighted, blundering, truculent beast, invariably uses its front horn-sometimes of considerable length-on a straight charge. If it misses its intended victim it will generally carry on and not return; it will never turn round to savage its victim as a buffalo will by kneeling, trampling and goring. The object of the rhino's charge is not to impale a person, but to toss; the black rhino lowers its head and if the horn makes contact will toss its victim into the air. Most injuries are from a front horn thrust on the buttocks, preliminary to a hoist and toss, as the victim is running away. There is the record of a European who was charged and found himself momentarily sitting on a rhino's head with the horns between his legs before he was flung clear. Another rhino which tossed and badly injured an African went off with its horn entangled in the sling of a rifle he was carrying. There are also authenticated reports of rhinos which had blundered into camps 
departing with cooking pots, and on one occasion the indispensable utensil under the bed, impaled on their horns.

C. H. Stigand, in Hunting the Elephant in Africa, pp. 35-7, gives a graphic account of how he was mauled in Nyasaland.

The black rhinoceros is sometimes badly injured fighting with its own kind, using the front horn and inflicting decp cuts on the shoulders and flanks; one thus wounded had a gash between the horns 5 inches deep. It is I believe correct to claim that neither the black nor the white rhino ever uses anything but the horn in offence.

The white rhino, although not aggressive like the black, will sometimes, such as in the mating season, or when it has been injured, or when a cow is with its calf, attack seemingly unprovoked, a human being. On one occasion an African woman picking cotton was gored and killed; on another a man hoeing his plot was chased and killed. A white rhino found dead in West Madi, Uganda, after a fight with one of its own kind had 16 horn wounds in its body. As the white rhino may grow an anterior horn as much as $3 \frac{1}{2}$ feet in length, which is often sabreshaped from constant "stropping" against brick-hard antheaps, the wounds it can inflict are terrible. I once watched two huge bull white rhinos early one morning having a desperate and very noisy battle, indeed it was the noise which first attracted my attention. They would slowly back away from each other and then charge head on, heads lowered and horns pointing forwards, squealing and snorting, then having madercontact up would come each ponderous head with a terrifically powerful jerk in an endeavour to gash its opponent with its long, sharply pointed horn. I could not stay to see the end of the fight though before I left both combatants were streaming with blood. It is possible, from the way in which it normally carries its head, very low, that the white rhinoceros in attack may endeavour to gore a victim, rather than to toss, but I have insufficient evidence to make a definite claim to this effect. 